\title{
The 'War on Terrorism'-Perspectives from Radical Islamic Groups*
}

\author{
Francesco Cavatorta
}

School of Law and Government, Dublin City University

\begin{abstract}
Contrary to both popular and academic belief, the 'War on Terrorism' launched by the United States has one very clear enemy: radical Islamism. The varied and complex world of Islamism has been reduced to one unitary enemy, and that enemy is being fought both militarily and ideologically. This paper analyses the impact that the War on Terrorism is having on its target and contends that the 'simplification' of the concept of radical Islamism by the US administration, while beneficial for the purely practical purposes of war, is very much detrimental to the understanding of such a phenomenon and leads to policy choices that deepen the fault lines between Islamists and the West. The paper concludes by arguing that the current War on Terrorism is running the risk of causing a 'return' of the jihadi Islamist ideology that had been comprehensively defeated within the vast Islamist world and that has been replaced by a much more pragmatic and much more peaceful approach to gaining political inclusion.
\end{abstract}

\section{INTRODUCTION}

Following the terrorist attacks on its territory in September 2001, the United States responded to the challenge of the new security environment by launching 'the War on Terrorism'. The first step in this war was the invasion of Afghanistan and the overthrow of the Taliban regime there. The war in Afghanistan served the purpose of eliminating a safe haven for al-Qaeda operatives and seemed to indicate that the priority of the US administration was to dismantle the international network that Osama bin Laden and his associates had created. This motive can be seen also in the very extensive efforts that were made to cut off financial support for al-Qaeda by seizing assets and implementing stricter measures for the control of the flow of finance internationally. ${ }^{1}$ One of the most interesting aspects about the war in

${ }^{1}$ For an overview of the financial aspect of international terrorism, see Matthew Levitt, 'The political economy of Middle East terrorism', Middle East Review of International Affairs 6 (4) (December 2002), 49-65.

*First presented at the conference 'War on Terror-Three Years On', at the Royal Irish Academy, Dublin, 26 November 2004.

Author's e-mail: Francesco.Cavatorta@dcu.ie

Irish Studies in International Affairs, Vol. 16 (2005), 35-50. 
Afghanistan is the low level of controversy it generated initially in the Arab and Muslim worlds. The regime of the Taliban did not enjoy much international support and the Muslim masses had never warmed to the Taliban's regressive social measures. Paradoxically, the invasion of Afghanistan even 'pleased' the ruling regime in Iran because of the strong rivalry that existed between the Taliban and the Iranian clerics. In fact, it is only when the military operations in Afghanistan had already begun that Arab public opinion started to be more sympathetic to bin Laden's cause, and this was largely due to the fact that bin Laden had mentioned the Palestinian question in one of his statements to al-Jazeera.

To some, the invasion of Afghanistan hid for a short period of time the inherent contradictions and the lack of clarity surrounding the 'War on Terrorism'. Daniel Pipes, a strong supporter of President George W. Bush, suggested that 'the administration chose this formula [the war on terrorism] precisely to avoid having to identify the enemy more clearly' ${ }^{2}$ The results of such ambiguity seem to have been the invasion of Iraq without any evidence for that country's support of international terrorism, the 'neglect' of bin Laden and the pressuring of the countries belonging to the so-called 'axis of evil', including countries that have very little to do with global terrorism.

This paper contends, on the contrary, that the objectives of the War on Terrorism are quite clear, that the target is easily identifiable and that the policies implemented have a desired outcome. The War on Terrorism is aimed at defeating or, at the very least, limiting the impact of radical Islam on the world stage and it is just a new, more radical phase of a rather long-standing policy that US administrations undertook after the end of the Cold War with varying degrees of intensity. ${ }^{3}$ It therefore becomes imperative to analyse how this policy is impacting on the enemy: the world of radical Islamism. The perspective of radical Islamic groups on the effects of the War on Terrorism, their interpretations of that 'war' and their reactions to it are of fundamental importance in order to obtain a preliminary picture of where the 'war' is leading us. The paper contends that the War on Terrorism may in fact achieve the opposite of the goal it set for itself and could inject 'new life' into a jihadist ideology that had been comprehensively 'defeated' due to its extremism, inherent authoritarianism and violence. A closer look at radical Islamic movements will show that the numerous preconceptions about these movements that are the starting point of many analyses are misplaced. Such movements vary greatly among themselves, are not often involved in violence to achieve power and underwent a process of political learning that makes them potential pro-democracy actors. In this respect, the marginalisation within the Islamist camp of both national and international jihadist groups committed to the use of violence and imbued with both virulent anti-Americanism and an ideological framework solidly based on the theory of a clash of civilisations is today in danger of being reversed, due to both direct and indirect US actions.

\section{THE WAR ON TERRORISM}

The 'War on Terrorism' is said to be vague in terms of its enemy, objectives and modus operandi. Much is made of President George W. Bush's statements regarding

2Lisa Anderson, 'Shock and awe. Interpretations of the events of September 11', World Politics 56 (2) (January 2004), 303-25: 313.

${ }^{3}$ For an extensive overview of the relationship between the US and political Islam, see Fawaz Gerges, America and political Islam. Clash of cultures or clash of interests? (Cambridge, 1999). 
the necessity to fight this war to defend values of some kind or other, and some 'see the Bush administration's response similarly as based not only on a definition of US interests but also on ideals which allowed that response to be framed as a struggle of good against evil'. ${ }^{4}$ Such a vision of good versus evil that emanates from the White House is to an extent genuine, ${ }^{5}$ but this should not obscure the fact that this vision may be a convenient simplification to gain latitude in decision-making terms. For instance, the invasion of Iraq cannot simply be explained by a vision of the world where good has to battle evil - it responds to a clear strategy that the US has in mind for the Middle East. In this context, the enemy is neither some vague international terrorist network bent on the destruction of the United States nor is it the rogue state members of the 'axis of evil'. For instance, no one seriously thinks that Cuba poses a vital security threat to the United States.

The War on Terrorism is not as vague as is often assumed. Technically, it is waged against the new security threats that the United States faces. These include terrorist groups and rogue states that may cooperate with them. However, the actions undertaken by the US since the attacks on New York and Washington, DC in September 2001 do not entirely reflect that. While the war in Afghanistan was consistent with the plan to rid the world of safe havens for terrorist groups, the war against Iraq is patently inconsistent with that objective. Contrary to that plan, Iraq has now become a hub for terrorist activities and, possibly more important, has become a new rallying cause for many individuals and groups across the Arab world. If we discard facile interpretations of the war in Iraq either as being one fought to rid the world of an impending menace (most objective analysts agreed that Iraq did not pose such a threat) or being about the necessity for the US to secure oil supplies, it emerges that the removal of Saddam Hussein is part of a strategy to have 'externally controlled processes of semi-democratisation' in a region where US dominance is widely contested by Islamism. The medium-term strategy seems to be the creation of a number of semi-democracies to secure both international stability and to crack down on radical opposition groups.

The starting point had to be Iraq because it is a leading country in the Arab world and because most other governments in the region already perform the function of guaranteeing key US interests in the region. At best, such a strategy would lead, in the longer term, to a true democratisation of the political system in the Middle East region and to a liberalisation of the economy, but only once all domestic political actors have accepted the primacy of the US. Opposition groups have to become 'reasonable'. At worst, it would leave in place governments that acquiesce to the United States' dominance of international affairs, but that do not enjoy popular legitimacy. In all this, the enemy seems to be what it has always been: radical Islamism. The concern about radical Islamism started with the shock of the Iranian revolution of 1979, but it became a truly major concern only after the end of the Cold War when the expansion of radical Islamist groups seemed to threaten the stability of a number of regimes, including those in Algeria, Egypt, Saudi Arabia and Tunisia. ${ }^{6}$ A cursory look at the list of terrorist groups that the State Department publishes indicates that the US administration identifies radical Islamism as enemy number one. ${ }^{7}$

${ }^{4}$ Anderson, 'Shock and awe', 305.

5Ron Suskind, 'What makes Bush's presidency so radical even to some Republicans?', New York Times Magazine, 17 October 2004, 44-51; 61; 102 and 106.

${ }^{6}$ Michael Salla, 'Political Islam and the West: a new Cold War or convergence?', Third World Quarterly 18 (4) (1997), 729-42.

${ }^{7} \mathrm{ABC}$ Online News, 'The enemies in the war on terror', 8 October 2002, available at 
Even a cursory look also indicates quite clearly that the US does not have much time for the subtleties of the region, for the differences that exist among many of these groups or for the degree of legitimacy their causes may have. Radical Islamist groups have been selected as the enemy for the following reasons:

- $\quad$ they wish to overthrow pro-Western governments in the Muslim world;

- they wish to destroy any Arab-Israeli peace process; and

- they wish to expel US forces from the Middle East.

To conclude, the War on Terrorism may not be the confused and confusing policy that some believe it is. Although the US administration may be mistaken in the belief that the current strategy will work, this should not obscure the fact that it has a clear enemy, preferred outcomes and a rather revolutionary modus operandi to achieve the goals it has set. The underlying logic of this policy is well explained by Fareed Zakaria, who argues that 'the Arab rulers of the Middle East are autocratic, corrupt, and heavy-handed. But they are still more liberal, tolerant, and pluralistic than those who would likely replace them'. ${ }^{8}$ This implies that the US should support these rulers until a more deserving political opposition enters the scene. Also, when given the chance, the US should work to replace the few unfriendly regimes that remain in place.

\section{THE NEBULOSITY OF RADICAL ISLAMISM}

Before detailing how the War on Terrorism influences the perceptions and the beliefs of prominent radical groups in the Arab world, it is important to outline the definitional debate that surrounds radical Islam. The starting point of the discussion should be the term 'Islamism', which best defines the type of groups we are dealing with. The term 'refers to the rise of movements and ideologies drawing on Islamic referents - terms, symbols and events taken from the Islamic tradition-in order to articulate a distinctly political agenda' ${ }^{9}$ The term refers specifically to those movements that largely contest what may be referred to as official Islam, which such movements see as supporting authoritarian regimes by conferring on them Islamic credentials that they do not fully deserve. According to Denoeux, the political project of Islamist groups is quite simple. Islamism "provides a comprehensive critique of the existing order, challenges it and aims to change it. It addresses the social, political, economic and cultural challenges faced by contemporary Muslim societies and claims to provide solutions to them'. ${ }^{10}$ Islamists are therefore very much concerned with providing a clear political alternative to the regimes in place in a number of Muslim countries.

The Islamist project is appealing to a large number of individuals because it represents a very definite departure from the failures of the current ruling regimes, particularly in the Arab world. Islamism thrives where political immobilism, subservience to foreign interests, poverty, illiteracy and lack of economic opportunities

http://abclocal.go.com/wabc/news/WABC_121101_terroristgroups.html (21 July 2005).

8Fareed Zakaria, 'Islam, democracy and constitutional liberalism', Political Science Quarterly 119 (1) (2004), 1-20: 2.

'Guilain Denoeux, 'The forgotten swamp: navigating political Islam', Middle East Policy 9 (2) (June 2002), 56-81: 61

10Denoeux, 'The forgotten swamp', 61. 
also thrive. ${ }^{11}$ There is very little doubt that ideologies like liberalism, socialism and communism are perceived to have failed, both as mobilising political credos, and in terms of satisfying people's needs including even their most basic economic needs'. ${ }^{12}$ In this context, the motto 'Islam is the solution' attracts considerable support and, even more importantly, is not an empty slogan given the amount of charitable work that the vast majority of radical groups have in place and given the powerful social activism they are engaged in. ${ }^{13}$ For instance, the semi-legal Moroccan association Jamiat al-Adl wal-Ihsan (Justice and Charity Group), through its social activism in the provision of essential social services to the most impoverished classes, demonstrates to ordinary Moroccans that it is possible to 'do things' differently in a country where corruption, poverty, illiteracy and lack of hope are rife. ${ }^{14}$

Such conditions are quite common throughout the region, and even the rich oilexporting states are suffering from lack of political legitimacy and very slow economic growth, which in turn has repercussions, for instance in terms of the growing rate of unemployment and the subsequent dissatisfaction of the workforce. It is no surprise that the solutions offered by Islamism are still very popular.

Thus, to a certain extent, all groups that embrace Islamism can be considered revolutionary, because their foremost objective is to change the societies they live in by radically transforming the political, social and economic relationships that currently exist. To highlight the point, Kamel al-Sayyid emphasises that 'all Islamists share the belief that the political systems of Muslim countries should be based on Islamic principles, giving Islam a central role in the political process' ${ }^{15}$

The demands that Islamists make on the respective political systems within which they operate appear radical because they generally entail the dismantling of the current structures of power. Thus, the Justice and Charity Group in Morocco would like to see the king relinquish his power and either resign or become some sort of constitutional monarch. The Muslim Brotherhood in Egypt would like to see an end to emergency laws and would like to fully participate in free and fair elections that would see President Mubarak's powers curtailed. The surviving members of the Islamic Front in Algeria would like an end to the rule of the military and their readmission to the political process. Hamas wants an end to the occupation of Palestine and the democratisation of Palestinian political life, which would include elections for the post of president, for the legislative council and for the local councils. Equally radical demands are made to turn around the respective economies of these countries, with a heavy emphasis on the introduction of liberal reforms (a process currently hijacked by corrupt elites), ${ }^{16}$ the re-investment of profits from the export of

\footnotetext{
${ }^{11}$ The data on the state of the region can be found in United Nations Development Programme and Arab Human Fund for Economic and Social Development, Arab human development report 2002: creating opportunities for future generations (New York, 2002).

${ }^{12}$ Azza Karam, 'Islamist parties in the Arab world: ambiguities, contradictions, and perseverance', Democratization 4 (4) (Winter 1997), 157-74: 160.

${ }^{13}$ Asef Bayat, 'Activism and social development in the Middle East', International Journal of Middle East Studies 34 (1) (2002), 1-28.

14John Entelis, 'Un courant populaire mis à l'ecart', Le Monde Diplomatique 589 (September 2002), 22-3.

${ }^{15}$ Mustapha Kamel Al-Sayyid, 'The other face of the Islamist movement', Working Papers, Carnegie Endowment for International Peace, 23 (January 2003), 1-32: 5.

${ }^{16}$ For an overview of the effects of neo-liberal reform in North Africa, see Bradford Dillman, 'Facing the market in North Africa', Middle East Journal 55 (2) (Spring 2001), 198-215. For a more general overview of the entire Middle East see Clement Henry and Robert Springborg, Globalisation and the politics of development in the Middle East (Cambridge, 2001).
} 
the natural resources of each country, the renegotiation of trade agreements with developed countries and an end to corruption. The radicalism of the Islamists' demands and the policies they may implement if given a chance to be in power also touches international politics, and in this respect the Islamist groups truly are 'revolutionary movements' in that they do not accept the international status quo on a number of issues. First is the issue of the occupation of Palestine and the role that the United States plays in supporting Israel, but there are also other topics of potential conflict with the US, and with the West in general, including the nature of the freetrade regime, and the 'export' of an individualistic and materialistic popular culture. It follows that the 'radicalism' of Islamism is forcefully expressed in the policies that Islamist groups would like to see implemented, and it is considered radicalism only because some of the groups may threaten established regional and Western interests. Most of their demands seem to be actually quite sensible: the end of authoritarian rule, the end of corruption, productive investments in infrastructure and education, social services for the impoverished masses, Arab unity and a geo-strategic realignment away from the United States and what is perceived as aggressive Western neo-colonialism. This general 'menu of actions' is purely indicative, and many groups would subscribe to these actions with varying degrees of support and, ultimately, it does not really matter if these are populist and unrealisable demands.

Thus, the Islamist camp is indeed radical in the sense that it is politically extreme because in order to achieve its objectives it needs to 'revolutionise societies'. However, the notion of radical Islam as a unitary actor fails to capture the complexities of the Islamist camp. The main problem from the perspective of many analysts seems to be the inability to distinguish between radical objectives and radical methods (i.e., the use of violence) to achieve them. In this context, there are three major points about radical Islam that should be dealt with.

\section{THE USE OF VIOLENCE AND ISLAMISM}

Violence as a method to create an Islamic state has never been the most prominent means employed. There is very little doubt that within the Islamist camp there are groups that attempted, and still attempt, to achieve state power through armed struggle. The doctrine that such groups rely on to justify their actions is based on the belief that current regimes in the Muslim world are 'infidel' and therefore they need to be eliminated. ${ }^{17}$ The population also needs to be intimidated into supporting change. The goal is the imposition of an Islamic state from above once this vanguard of warriors has taken power. For a time, this strategy had some appeal, but not to the extent that is often believed. Thus, it should be highlighted that 'the majority of Islamists do not engage in acts of armed resistance' 18 or terrorism and prefer to act through social activism or the political process when possible. In fact, the use of violence has backfired on groups dedicated to it because it has both strengthened the resolve of authoritarian regimes to survive and it has alienated vast sectors of the population, which felt indiscriminately targeted. Thus, the association between Islamic radicalism and violence characterises a very small number of Islamist groups, which have been marginalised even within the Islamic camp itself. A notable

\footnotetext{
17The Egyptian intellectual Sayyid Qutb popularised this ideology in modern times. See Roxanne Euben, Enemy in the mirror: Islamic fundamentalism and the limits of modern rationalism (Princeton, 1999).

${ }^{18} \mathrm{Al}$-Sayyid, 'The other face of the Islamist movement', 5.
} 
example is the disowning of the Algerian Armed Islamic Groups (GIA) by the Islamic Front during the Algerian civil war.

The jihad to overthrow the regimes in power has been notably unsuccessful in Egypt, Syria and Algeria and has led some movements to admit that armed struggle was not the way forward and should in fact be completely abandoned in favour of peaceful means to achieve the creation of an Islamic state. This is the case of the Egyptian al-Jama'a al-Islamiyya, which declared an end to violence as early as 1996. The 'Initiative on the cessation of violence' had been agreed upon among the imprisoned historical leaders of the group, and 'the clearest sign of the widespread acceptance of the call for non-violence by the followers of Al Jama' a al-Islamiyya and the Jihad Group is that no acts of armed resistance to the government by Islamists have taken place in Egypt since the Luxor massacre'. ${ }^{19}$ The Islamic Front in Algeria came to a similar conclusion and abandoned violence in the hope of being re-integrated in the political system, in recognition of the failure to overthrow the regime through violence. ${ }^{20}$

French scholars Olivier Roy and Gilles Kepel may be correct when arguing that 'political Islam' as an ideology of imposition from above has failed to achieve its goals and does not exercise any attraction among the vast majority of Muslims. When violence enters the equation, radical Islamic groups fail miserably and their ideology of takfir (declaring that individuals or groups previously considered Muslims are in reality non-believers and can therefore be legitimately fought) has lost most of its appeal..$^{21}$ The assumption that violence has not played such a major role in the Islamist camp and that it lacks the support of the population is not shared, however, by those who point to the actions of groups such as Hamas and Hezbollah.

However, the case of the Palestinian Hamas and Lebanese Hezbollah and their 'espousal' of violence are very different from the case of al-Qaeda, although they are often lumped together. In the cases of both Hamas and Hezbollah the use of violence is intimately linked to the objective of 'territorial liberation' and not to the goal of creating an Islamic state. The accusations of terrorism that both organisations have to contend with are rejected by their leaderships. In the case of Hamas, its leaders point out that they target Israeli citizens and use 'human bombs' because of the military advantage that Israel enjoys. ${ }^{22}$ Hamas does not seek the imposition of an Islamic state through violence. In the case of Hezbollah, terrorist operations are limited to the area that Israeli troops still occupy in Southern Lebanon, and such operations target Israeli soldiers and Lebanese collaborators. In the rest of Lebanon, Hezbollah is not involved in the use of violence to further its political goals and is in fact a respected member of the political system, attracting support outside its core Shi'a constituency. Hezbollah recognises that Lebanon will not become an Islamic state and is not bent on creating one through armed struggle. ${ }^{23}$ Furthermore, terrorist operations represent only a small part of what both organisations do. They are very much involved in the provision of social services, they involve themselves in extensive political activity and they proselytise.

\footnotetext{
${ }^{19} \mathrm{Al}-$ Sayyid, 'The other face of the Islamist movement', 16.

${ }^{20}$ Lounis Aggoun and Jean-Baptiste Rivoire, Françalgérie:crimes et mensonges d'états (Paris, 2004).

${ }^{21}$ Olivier Roy, L'Echec de l'Islam politique (Paris, 1992) and Gilles Kepel, Jihad: ascesa e declino (Rome, 2000).

${ }^{22}$ Abd al-Aziz Rantisi, Sheikh Ahmed Yassin, Ismail Abu Shanab and Mahmoud al-Zahar, 'Interviews from Gaza: what Hamas wants', Middle East Policy, 9 (4) (December 2002), 102-15.

23Judith Palmer Hark, Hezbollah. The changing face of terrorism (London, 2004).
} 


\section{ISLAMISM, POLITICAL LEARNING AND DEMOCRACY}

The vast majority of radical Islamic groups have gone through a process of political learning and have recognised for some time the necessity to engage peacefully with the political system in order to have their preferred policies implemented. This is the result both of an ideological shift and of tactical adjustments and has led to the belief that radical objectives can be obtained through less than radical methods. In addition, movements such the Tunisian al-Nadha never advocated nor justified violence, even in the face of authoritarianism.

In this context, participating in the political system has become a priority for such groups, and they have tried to enter the political arena by calling on the ruling regimes in the Middle East to open up the system to free and fair competition for votes. Radical Islamic groups throughout the region have sought political recognition, have participated in elections when and where they have been held and have engaged with other opposition movements in order to maximise the pressure on the ruling elites to reform. This is often not taken into account in analyses of Islamic movements, to the detriment of a fuller understanding of what these movements actually stand for and can contribute in terms of democratisation in the region.

The starting point should be the acknowledgement that all these movements operate in highly authoritarian environments and that their radicalism may, in fact, not be so 'extreme' after all. We are far from the scenarios that characterised the actions of terrorist groups such as the Italian Red Brigades in Western Europe in the 1970s, despite the efforts of most governments in the Arab world to present radical Islamists in such a light. The governments of Western Europe were liberaldemocracies, had legal outlets for political dissent, were providing for their citizens and envisaged a prominent role for political opposition. This is not the case for regimes in the Arab world, where not one regime enjoys credible democratic legitimacy. ${ }^{24}$ The majority of radical Islamic groups have today an advanced agenda in favour of procedural democracy that should be highlighted more clearly.

The following examples may shed some light on this point. The Islamic Salvation Front (FIS) in Algeria took advantage of the political reform carried out by the ruling regime in the late 1980s to fully participate in the first free and fair democratic elections the country had known and won a spectacular victory. However, it was subsequently deprived of that victory through a military coup that found much support in the United States and Europe. ${ }^{25}$ While it acted as a legal political party, the FIS leadership often spoke of the value of procedural democracy and of the necessity for the country's rulers to be periodically sanctioned by the popular vote. ${ }^{26}$ Morocco is another interesting case study because it has two large Islamic movements. The first is the Party for Justice and Development (PJD), which operates as a legal movement, participates in elections and works within the admittedly 'rigged' system. The logic behind the PJD's participation in an authoritarian political system, which excludes the party from having any real power, is that it is better to have a voice than to be completely excluded. The second Islamic movement in

\footnotetext{
${ }^{24}$ Alfred Stepan and Graeme Robertson, “An "Arab" more than "Muslim” electoral gap', Journal of Democracy 14 (3) (July 2003), 30-44.

${ }^{25}$ Francesco Cavatorta, 'Geopolitical challenges to the success of democracy in North Africa: Algeria, Tunisia and Morocco', Democratization 8 (4) (Winter 2001), 175-94.

${ }^{26}$ Francois Soudan and Samir Gharbi 'Les Islamistes, victimes de la guerre', La Jeune Afrique 1578 (27 March-2 April 1991), 48-50.
} 
Morocco is the semi-legal association Jamiat al-Adl wal-Ihsan. This group does not seek a direct political role for two reasons. First of all, participating in the system would put the association under the spotlight, and many of its charitable and social activities would be scrutinised even further by the ruling regime. Secondly, the association's leadership believes that radical changes in the procedure of the political system should take place before they would enter that system, otherwise they would end up legitimising an authoritarian system, which then would have no incentives to reform. An interesting aspect of the Jamiat al-Adl wal-Ihsan association is its emphasis on political reforms: a call for political institutions in Morocco to become accountable and for the political process to be liberalised.

In his memorandum, the leader of Jamiat al-Adl wal-Ihsan, Sheikh Yassine, calls for the end of the rigging of elections and wants the king to end the pretence at democracy in Morocco. He asserts that there has been only a façade of democratic measures implemented so far (labelled ratatouille makhzenienne). ${ }^{27}$ The current political arrangements should be replaced with a truly new method of governance based on the procedures of democracy. According to Yassine 'democratic rule, meaning in short the freedom and the right of the people to choose their own government, is the only way out of the darkness of authoritarianism' .28 In the context of Moroccan politics, this is quite a revolutionary position. Moreover, even the oldest and most important Islamic group in the Middle East, the Egyptian Muslim Brotherhood, has quite consistently refrained from supporting violence and has repeatedly sought political recognition from the government with the objective of contesting elections. ${ }^{29}$ The Syrian Muslim Brotherhood, which was involved in a failed armed insurrection against the late President Assad in the late 1970s and early 1980 s, has since radically revised its stance on the use of violence and is now campaigning for political democratisation. ${ }^{30}$ The same could be said for Hamas and Hezbollah. These two organisations are not jihadist groups attempting to create an Islamic state by terrorising the civilian population and by targeting government officials. Assessing the post-Arafat situation in the Occupied Territories, Khaled Amayreh emphasised that Hamas was 'going to become more mainstream'. ${ }^{31}$

Critics would argue that 'talk' is cheap and that all these groups mainly use the rhetoric of democracy to trick their way into power. After having reached the position they aspire to, they would simply abolish democracy and install a different authoritarian regime. While there is no evidence to support this assumption, there is some evidence to sustain the argument that the commitment of radical Islamist groups to democratic procedures and practices may not be simply the product of political expediency, but may also be the result of an ideological shift. Furthermore, there is considerable evidence that when Islamists are forced to operate in a "more competitive' political system, they find themselves having to compromise. The

${ }^{27}$ Abd Assalam Yassine, Mémorandum: à qui de droit, which can be regarded as the political manifesto of Yassine and of the Jamiat al-Adl wal-Ihsan association, is available at http://www.yassine.net//lettres/memorandum.htm (22 July 2003). The original version of the document is in French and the author translated it into English. However, an English version of the text is now available at the above mentioned web address.

${ }^{28}$ Yassine, Mémorandum, 17.

${ }^{29}$ The Brotherhood's political program can be found in 'Brotherhood steps into the fray', Al Aharam Weekly, 11-17 March 2004, available at http://weekly.ahram.org.eg/2004/681/eg3.htm (18 March 2004).

${ }^{30}$ Alan George, Syria: neither bread nor freedom (London, 2003).

${ }^{31}$ Khaled Amayreh, 'Hamas eyes its future role', Al Ahram Weekly, 4-10 November, 2004, available at http://weekly.ahram.org.eg/2004/715/re12.htm (10 November 2004). 
power of socialisation to the norms of political and social pluralism should not be underestimated. Daniel Brumberg emphasises, as an example, that 'while Lebanon's Hezbollah is not, philosophically speaking, a champion of pluralism, in practice its leaders do not favour and cannot favour the imposition of an Islamic state' ${ }^{32}$

First and foremost, Islam does not prescribe any particular regime or political system and the religion can be used to legitimise a wide range of diverging political systems. Thus, there is no reason why Islam cannot be re-interpreted and used to sustain democratic procedures. ${ }^{33}$ The vast majority of radical Islamic groups are the protagonists of this process of implicit re-interpretation. This does not mean that there are no intellectual efforts to do the opposite, but those seem to be a minority within the larger Islamic camp. ${ }^{34}$

Second, all of these radical Islamic movements operate in authoritarian environments and, in order to attract support, they have to be capable of offering an alternative ideology and an alternative mode of behaviour that are perceived as being significantly different from the ones characterising the ruling regime. The language and the practice of democracy provide that particular alternative. A closer look at these movements highlights how their internal dynamics exhibit both a high degree of 'pluralism' and political pragmatism.

On the issue of pluralism, it should be emphasised that, despite the presence of a highly charismatic leadership among radical Islamic movements, fundamental decisions and changes in policies are also the product of wide internal consultations. The decision taken by the Algerian Islamic Front to contest the 1991 legislative elections despite the imprisonment of two of the group's leaders was, for example, the outcome of an open and democratic party congress. The involvement of ordinary members in making vital decisions for the organisation is also a feature of the Moroccan Justice and Charity Group. One instance of such decision making would be the U-turn the association made on the reform of the family code implemented by the king between 2003 and 2004. As would be expected, an intense debate occurred around such an important reform, with the king arguing for a complete revision of the previous family code and its transformation towards the granting of effective equality to women. When the new legislation was first presented, it faced substantial opposition from the Jamiat al-Adl wal-Ihsan. After the legislation was adopted with some revisions that were more in tune with the perceived Islamic ethos of the country, the association did a spectacular turnaround on its view of the family code and today believes that the law does not go far enough in terms of equality. The association's members themselves, particularly the women within the association who perceived the reform as being both in line with Islam and their interests, brought about this turnaround. ${ }^{35}$ Even the groups involved in a national liberation struggle consult their members and the wider community to legitimise their policies and actions. Such is the case with Hamas, which carried out a very intense internal debate on the issue of the organisation's participation in the Palestinian presidential elections of 1996. ${ }^{36}$

32Daniel Brumberg, 'Islamists and the politics of consensus', Journal of Democracy 13 (3) (July 2002), 109-115: 112 .

${ }^{33}$ This point is made by, among others, John Esposito, Unholy war. Terror in the name of Islam (New York, 2002).

${ }^{34}$ For an overview of the complex relationship between Islam and democracy, see Hugh Goddard, 'Islam and democracy', Political Science Quarterly 73 (1) (January/March 2002), 3-9.

${ }^{35}$ Pascale Harter, 'Changing status of Morocco's shunned wives', 24 January 2004, available at http://news.bbc.co.uk/2/hi/africa/3435153.stm (18 August 2005). The same point is made in Wendy Christiansen, 'Débats entre femmes en terres d'Islam', Le Monde Diplomatique 601 (April 2004), 20-1.

${ }^{36}$ Shaul Mishal and Avraham Sela, The Palestinian Hamas (New York, 2000). 
On the point of pragmatism, it should be emphasised that most of these groups are capable of modifying their strategies and making their absolutist goals more flexible. The cases of Hamas and Hezbollah are again paradigmatic in this sense. Despite the conventional wisdom that sees Hamas as forcefully pursuing the two absolutist goals of the liberation of the whole of Palestine and the Islamisation of Palestinian society, the evidence points to a rather high degree of flexibility and pragmatism in the organisation. As Gunning argues 'alongside this absolutist set of goals, and in competition with it, resides a more pragmatic, flexible set of objectives'. ${ }^{37}$ This is why Hamas has attempted to Islamise society without actually confronting the secular Palestinian organisations and has, at all times, attempted to not split the Palestinians. It is also the reason why its attitude to the Israeli-Palestinian peace process is more mixed and less militant than is usually believed. The attempts made to wreck the Oslo agreement are not the product of an a priori unwillingness to reach a compromise with Israel, but are based on the belief that the Oslo agreement is bad for the Palestinians. Thus, the current stalemate in the peace process is the result of what Hamas and a great majority of Palestinians see as a 'bad agreement'.

Finally, radical Islamic groups have been able to demonstrate that they can form tactical alliances with other political movements that operate under the same authoritarian constraints. The Muslim Brotherhood in Egypt has, for instance, been able to run its candidates thanks to a tactical affiliation with a party of the left. The Islamic Front in Algeria enjoyed the sympathy of some parties on the left after having been deprived of its electoral victory and, while at odds with the FIS ideology and political objectives, those parties campaigned for the FIS's re-admission to the political fold. ${ }^{38}$ In Morocco and Tunisia, the Islamists are increasingly building links with human-rights associations in order to obtain 'protection' from government abuses. ${ }^{39}$

\section{Transnational Islamism}

It is often argued that one of the strengths of the Islamist ideology is its 'transnationalism'. According to Dalacoura, 'Islamism [...] based on the notion that the umma (community of believers) must overcome the state because it is an artificial creation which fragments the natural unity of believers, questions the very foundation of the political establishment in the Middle East' 40 and is also potentially destabilising for the international community as a whole. There is very little doubt that the history of Islamism is a very international one and that links among different movements exist at multiple levels. George argues that it is undeniable that Islamist movements in the Middle East have spread very quickly and in a transnational manner, through a network of intellectual and political

\footnotetext{
37Jeroen Gunning, 'Peace with Hamas? The transforming potential of political participation', International Affairs 80 (2) (March 2004), 233-55.

${ }^{38}$ Marco Impagliazzo and Mario Giro, Algeria in ostaggio. Tra esercito e fondamentalismo, storia di una pace difficile (Milan, 1997).

${ }^{39}$ For the Tunisian case, see Kamel Labidi, 'Mascarade électorale en Tunisie', Le Monde Diplomatique (607) (October 2004), 3. For Morocco, see Journal of Maghreb Culture, 3 October 1999, available at http://www.geocities.com/CapitolHill/Lobby/3385/Main.html (1 November 2004).

${ }^{40}$ Katerina Dalacoura, 'Islamist movements as non-state actors and their relevance to international relations', in Daphne Josselin and William Wallace (eds.) Non-state actors in world politics (Basingstoke, 2001), 235-48: 236.
} 
contacts between societies', ${ }^{41}$ and a recent investigation by Jeff Haynes bears this out. ${ }^{42}$ The existence of such transnational links has led some commentators either to tar all Islamic movements with the same brush or, even worse, to see an international Islamic conspiracy with the objective of antagonising the West in the name of the cultural superiority of Islam, which is at the moment in an inferior position with respect to Western liberal countries. ${ }^{43}$ Added to this is the perception that such an 'Islamic international' is employing violence as its most preferred means of action. The existence of al-Qaeda seems to confirm such views.

However, the picture painted of a violent transnational Islam is not quite accurate. Dalacoura again emphasises that "most connections between Islamist movements across state boundaries are of a cultural, social and political nature. Representing the Islamist movement as a predominantly violent one is not accurate' ${ }^{44}$ Furthermore, it should be highlighted that Islamic movements, while sharing certain policies and specific solutions for the challenges facing the societies in which they operate, also have important differences with each other that arise from their respective national contexts. The degree of authoritarianism they generally face differs, the Islamic legitimacy of the regimes in power varies greatly, the problems that various Islamic societies face are also rather different and all this indicates that Islamic movements are much more the product of local circumstances than the outcome of the actions of an 'Islamic international'. This is why the Islamist movements are individually much more concerned with getting into power in their own nation-states. As Fred Halliday points out 'transnational links may help in the spread of the Islamist message throughout the region and contribute to the ascendancy of Islamist movements. But despite their professed ideology, the Islamists in each country seek to take over their own states'. ${ }^{45}$

All Islamic groups and movements continuously emphasise their independence from external sources of influence and stress the indigenous nature of their political project, while recognising that there are shared themes and values with other similar groups in the region.

\section{THE WAR ON TERRORISM AND RADICAL 'ISLAMS'}

The complexity of the Islamist camp, and the existence of many different radical 'Islams', clashes with the facile picture of terrorism and Islamism that the War on Terrorism paints. Such complexity is purposefully dismissed in order to avoid changing the fundamentals of US foreign policy in the region. That policy is centred on unwavering support for Egypt and Saudi Arabia, with the assumption that regional stability can be best guaranteed by authoritarian governments who accept the international status quo.

This policy is not simply put forth as a 'cold calculation' derived from the imperative of the US national interest, but it is given a moral dimension by arguing that current authoritarian regimes in the Middle East are better than what may come

${ }^{41}$ David George, 'Pax Islamica: an alternative New World Order?', in A.S. Sidahmed and A. Ehsteshami (eds), Islamic fundamentalism (Oxford, 1996), 11-33.

42Jeffrey Haynes, 'Transnational religious actors and international politics', Third World Quarterly 22 (2) (2001), 143-58.

43Judith Miller, 'The challenge of radical Islam', Foreign Affairs 72 (3) (Spring 1993), 43-56.

${ }^{44}$ Dalacoura, 'Islamist movements as non-state actors', 238.

${ }^{45}$ Fred Halliday, Islam and the myth of confrontation: religion and politics in the Middle East (London, 1996). 
to power in the future. However, the current targeting of Islamism has very little to do with its 'un-democratic nature' or its perceived regressive social practices, otherwise support for Saudi Arabia would have ended a long time ago. It has to do instead with the 'adversarial' nature that Islamism has when it comes to question the political, economic and cultural decisions that the Western-dominated international community takes. The various radical Islamic groups in the Middle East are very different from one another in terms of organisation, leadership, political philosophy and the activities they undertake; but they all share a harsh criticism of the current state of their countries and the position of subordination that they have on the international stage. This leads them to offer alternative policies that may harm the interests of Western countries in the region. This is why Islamist groups are being opposed and this is why the current War on Terrorism is confirming to the more militant sections within Islamism that the US and the West are abusing their power to victimise Islam. One of the leaders of Hamas, Abd al-Aziz Rantisi, stated that 'When Mr. Bush spoke about Crusades, he aroused a deep historical hatred in this region', ${ }^{46}$ and this view is increasingly shared.

From the perspective of radical Islamic groups, the War on Terrorism had three distinct effects on their beliefs and on their actions. First, direct American intervention in the region through military invasion has popularised anti-American sentiments once again. In particular, the fringe violent groups within Islamism have seen their beliefs in the theory of the clash of civilisations confirmed and are now directly engaging the US military. While it is too early to pass judgement on the long-term consequences of the US invasion of Iraq, there is some evidence to support the argument that the more militant groups have found a new cause to rally their troops. This is the opinion of former UN inspector Scott Ritter, who argues that the current US military operations in the Sunni triangle '[mean] more years of conflict in Iraq that will result in thousands more killed on both sides, and incomprehensible suffering for the people of Iraq, and unpredictable instability for the entire Middle East'. ${ }^{47}$

In addition, the inevitable excesses of the US military beamed across the Arab world by satellite television, and through non-Western sources of information, lead to further radicalisation. It should be emphasised that anti-Americanism was always a trait of radical Islam, but for a long time, with due exceptions, this had to do with politics rather than blind cultural hatred for the values the US represented. ${ }^{48}$ Specific aspects of American politics were targeted for criticism, but this may be changing; and if the situation slides further towards cultural conflict, the possibility of a dialogue decreases. Some argue that this has always been the case and that "the nature of Islamist anti-Americanism is cultural rather than political or military' ${ }^{49}$ and although this is an unsubstantiated claim today, it may become true in the near future.

Second, the continued support of the United States for authoritarian regimes indirectly contributes to aggravate the domestic political position of all radical Islamic movements, as no distinction is made between the violent Islamic opposition groups and the peaceful ones. This is why the 'double standards' that the United

${ }^{46}$ Abd al-Aziz Rantisi et al., 'Interviews from Gaza', 115.

${ }^{47}$ Scott Ritter, 'Squeezing jello in Iraq', 13 November 2004, available at http://www.aljazeera.net (13 November 2004).

${ }^{48} \mathrm{John}$ Waterbury, 'Hate your policies, love your institutions', Foreign Affairs 82 (1) (January-February 2003), 58-69.

${ }^{49}$ Reuven Paz, 'Islamists and anti-Americanism', Middle East Review of International Affairs 7 (4) (December 2003), 53-61. 
States supposedly employs to deal with democratisation in the Middle East region are again to the fore in debate. One of the clearest examples of this is the Algerian case. While the Clinton administration tended to be more 'neutral' with respect to the Algerian civil conflict and periodically reminded the Algerian military regime that it needed to come to terms with the fact that the Islamists must be brought back into the political fold (with conditions attached), the global War on Terrorism has seen a major shift in policy. It follows that 'American attitudes towards Algeria's domestic war on terrorism...have accorded priority to containing civil violence through tolerance of the government's policy of eradicating the "Islamist threat" by military means' ${ }^{50}$ In line with this, all the other regimes in the region have taken advantage of the American war on global terrorism to further tighten the screw against Islamic political opposition. The paradox is that 'mad dog' Gaddafi is now heralded as being a man of vision for having in the past pointed to Islamism as a dangerous force to be dealt with through harsh repressive measures. In a recent interview with the BBC, Colonel Gaddafi's son, asked whether Libya was now an ally of the US in the war on terror, replied 'yes, I think so'. ${ }^{51}$

The Casablanca terrorist attacks of May 2003, which were carried out by a small jihadi group, allowed the ruling Moroccan regime to crack down on the entire Islamic opposition with no differentiation between the different movements. The United States did not react to these massive abuses by calling the Moroccan authorities to account, but instead praised the efforts of the regime in cracking down on terror and promptly signed a free-trade agreement with the country. This approach is radicalising certain sectors of Islamism, which also take advantage of the poor social and economic conditions of their country to promote the ideology of takfir. ${ }^{52}$

For the first time in years, Egypt suffered a terrorist attack on its tourist industry with the bombing of the Taba Hilton Hotel in October 2004 at the hands of local militants, indicating that the previous cessation of violence from militant Islamic groups may not bind a new generation of jihadists. This attack may be the product of Mubarak's unwillingness to reform the country's political system, Egypt's perceived subservience to the United States and the contradictions that the international community encounters when dealing with the Arab-Israeli conflict.

The Tunisian president, Ben Ali, was re-elected in October 2004 through a very doubtful electoral process with no complaints from the United States or Europe, and he is often praised for having eliminated Islamism as a political force in his country. ${ }^{53}$ The War on Terrorism has also given Israel the chance to deal even more harshly with the Palestinian Islamic groups, and the 'targeted assassinations' of Hamas leaders Sheikh Yassine and Abd al-Aziz Rantisi in the Gaza Strip in March and April 2004, respectively, did not seem to disturb the American administration.

Finally, the rhetoric of democratisation that the US administration constantly employs is, from the perspective of radical groups, being misused. This tends to 'cheapen' the value of democracy, and US efforts such as the Greater Middle East Initiative are derided as being simply a propaganda coup because there is no interest

${ }^{50}$ Abdelaziz Testas, 'The United States' approach to Algeria's civil conflict: implications for democratisation, internal peace and anti-American violence', Democratization 11 (2) (April 2004), 87-120: 87.

${ }^{51}$ Mike Donkin, 'Saif Gaddafi's vision for Libya', 16 November 2004, available at http://news.bbc.co.uk/1/hi/world/africa/4014147.stm (16 November 2004).

${ }^{52}$ Selma Belaala, 'Misère et djihad au Maroc', Le Monde Diplomatique 51 (608) (November 2004), page 1 and page 16 .

${ }^{53}$ Ali Lmrabet, 'A Tunis, rien de nouveau', Le Journal Hebdomadaire, 180 (30 October-4 November 2004), 34-5. 
on the part of the United States to engage with radical Islamist groups. If its rhetoric of democracy were to be true, it is argued, the United States should pressurise its friends into accepting political reforms instead of fighting wars in the Middle East in the name of democracy. After all, it would be much less controversial and far easier to put pressure on friends and allies than to establish a democracy through the use of violence, as President Bush himself had promised he would do. ${ }^{54}$ However, that the rhetoric of democracy is just rhetoric is confirmed by the fact that, as suggested by one of Bush's policy advisers, 'sometimes it is necessary for the president to stand up with Bin Ali or Mubarak or others who are not models of democracy'. ${ }^{55}$ Why this is necessary is not really explained, though.

In a scathing critique of the Greater Middle East Initiative launched by the Bush administration, Rahul Mahajan argues that it is indeed a strategy, but not one of freedom. His attention focuses in particular on the contradiction that exists between the goal of democratisation and the goal of regional stability, which cannot be ensured given the presence of a political opposition that is 'unreasonable'. Thus, '[the US] will be overjoyed to have elections as long as there is only one candidate (of whom they approve) or as long as the result is under control, the way it would be in Afghanistan' ${ }^{56}$ Influential Muslim scholar Yusuf al-Qaradawi makes a similar point: 'the US government wants us to reform ourselves. There is no doubt, however, that a US-envisaged reform will only serve US championed interests' ${ }^{57}$ Yusuf AlQaradawi belongs to the Muslim Brotherhood and is often referred to as an 'Islamic centrist' because of his theological attacks on those who interpret in a literal manner the Islamic holy texts and because of his disagreements with the secular liberal elements in the Muslim world. With regard to the War on Terrorism, the influential sheikh declared to the newspaper Le Monde: 'I was among the first to denounce the attacks of September 11th! However, the US adopted an aggressive stance against Islam and the Muslim world. I stand against their unwavering support for Israel and their war in Iraq' ${ }^{58}$ It is precisely because of his views on international issues that he is no longer allowed to travel to the US.

\section{CONCLUSION}

As it is today conceived and carried out, the War on Terrorism is unlikely to achieve the long-term objective of regional stability in the Middle East and North Africa. The policy is based on the assumption that there is very little 'complexity' within Islamism and that all radical groups are potentially dangerous and threatening to US interests. Furthermore, there is an assumption that radical Islamist groups are mostly engaged in violent activities and that there is a very high degree of transnationalism involved, which makes these groups all the more dangerous. While this is the case for groups such as al-Qaeda, such assumptions do not find much correspondence with the reality of radical Islam. While most radical groups share some ideological

\footnotetext{
${ }^{54}$ George W. Bush, speech before the National Endowment for Democracy, on 6 November 2003, as reported in the New York Times, 7 Novemebr 2003.

${ }^{55}$ Danielle Pletka, senior staff member for Near East and South Asia Affairs with the Senate Committee on Foreign Relations, interview on al-Jazeera, Tuesday, 18 May 2004, available at http://www.aljazeera.net (1 November 2004).

56Rahul Mahajan, interview on al-Jazeera, Tuesday, 18 May 2004, available at http://www.aljazeera.net (1 November 2004).

57Yusuf al-Qaradawi, interview on al-Jazeera, Thursday, 20 May 2004, available at http://www.aljazeera.net (1 November 2004).

58Yusuf al-Qaradawi, interview in Le Monde, Tuesday, 31 August 2004, 24.
} 
tenets and some policy preferences, they are very much an 'indigenous' product of their national environments and therefore are very different from one another. Also, most radical groups are not involved in violence and specifically condemn its use for political purposes because it is both against 'true' Islam and because it is politically counter-productive. These groups prefer to focus on the provision of social services and on proselytising. In addition, most radical groups have attempted and still attempt to enter the political arena on an equal footing with other political formations and aim at competing on a pluralist stage. This makes them, potentially, actors for democratisation in the region. Islamism is a threat to the United States in so far as it would want to implement policies that challenge the status quo, and while in the short term this may be indeed detrimental to US and European interests in the region, in the long term it might turn out to be beneficial in terms of stability.

However, such complexity escapes the logic of the War on Terrorism, whose main objective seems to be the creation and support of states presenting a façade of democracy but that are supine to US interests and are able to keep Islamism under control by whatever means necessary, as the Algerian case demonstrates. This policy is, unfortunately, not bearing much fruit and we are currently witnessing a return of violent, militant Islamism spurred on by a logic of 'demonisation of the United States in an apocalyptic sense within a concept of a war that heralds the end of the world'.59 This type of virulent Islamism had been politically and ideologically defeated due to the misery it brought to much of the Middle East region, but it is now in danger of being revived. The current US approach is injecting new life into the takfir ideology and it is weakening the forces that support true democratic changes and dialogue, which include the vast majority of Islamic parties. In the long run this cannot but give rise to further anti-American violence. 